ISSN: 2302-8556

E-Jurnal Akuntansi Universitas Udayana

Vol.27.1.April (2019): 594-615

DOI: https://doi.org/10.24843/EJA.2019.v27.i01.p22

\title{
Pengaruh Asimetri Informasi, Ukuran Perusahaan, dan Employee Stock Ownership Program pada Praktik Manajemen Laba
}

\author{
Anak Agung Istri Sarasmitha Dewi ${ }^{1}$ \\ I Gusti Ayu Nyoman Budiasih ${ }^{2}$
}

${ }^{1,2}$ Fakultas Ekonomi dan Bisnis Universitas Udayana (Unud), Bali, Indonesia e-mail: sarasmithadewi@gmail.com

\begin{abstract}
ABSTRAK
Penelitian ini bertujuan untuk mendapatkan bukti empiris mengenai pengaruh asimetri informasi, ukuran perusahaan, employee stock ownership program pada praktik manajemen laba.Asimetri informasi diukur dengan relative bid-ask spread, ukuran perusahaan diukur dengan menggunakan ln (total aset), dan employee stock ownership program dengan jumlah proporsi saham yang dikelurkan oleh perusahaan untuk karyawan. Penelitian ini dilakukan pada perusahaan yang terdaftar di BEI yang mengadopsi ESOP pada tahun 2014 sampai dengan 2016. Teori yang mendasari penelitian ini yaitu teori keagenan. Metode yang digunakan untuk penentuan sampel yang digunakan adalah purposive sampling. Sampel perusahaan dalam penelitian adalah 14 perusahaan dengan 42 amatan. Pengumpulan data menggunakan metode observasi non partisipan. Teknik analisis data yang digunakan adalah analisis regresi linear berganda.
\end{abstract}

Kata Kunci: Asimetri informasi, manajemen laba.

\begin{abstract}
This study aims to obtain empirical proves the effect of information asymmetry, firm size, employee stock ownership program on earnings management practices. Information symmetry is measured using relative bid-ask spreads, firm size is measured using ln (total assets), and employee stock ownership program with the proportion of shares disbursed by the company for employees. This research was conducted on companies listed on the Stock Exchange that adopted ESOP in 2014 until 2016. The theory underlying this research is agency theory. The sampling method used in this study was purposive sampling. The sample of companies in the study were 14 companies with 42 observations. Data collection uses non-participant observation methods. The data analysis technique used is multiple linear regression analysis.
\end{abstract}

Keywords: Information asymmetry, earnings management.

\section{PENDAHULUAN}

Laporan keuangan perusahaan merupakan cerminan dari kondisi perusahaan karena di dalam laporan keuangan terdapat informasi-informasi yang dibutuhkan oleh pihak yang memiliki keperluan dengan entitas. Laporan keuangan juga menjadi pertanggungjawaban bagi pihak manajemen perusahaan kepada pemegang saham dan menjadi sumber evaluasi bagi kinerja manajemen. 
Anak Agung Istri Sarasmitha Dewi dan I Gusti Ayu Nyoman Budiasih. Pengaruh ...

Informasi-informasi yang terdapat didalam laporan keuangan tersebut yang dibutuhkan oleh pihak internal dan eksternal adalah laporan laba rugi perusahaan.

Informasi mengenai laba sering menjadi target rekayasa atau manipulasi oleh manajemen. Hal tersebut dilakukan agar laporan keuangan terlihat baik dari period ke periode. Merekayasa tingkat laba yang dilakukan oleh pihak manajemen disebut dengan manajemen laba (Fahmi 2015). Manajemen laba menjadi salah satu faktor yang dapat mengurangi kredibilitas laporan keuangan karena laporan keuangan merupakan bentuk pertanggungjawaban perusahaan kepada seluruh pemangku kepentingan yaitu pemerintah, manajemen, kreditur, dan investor. Manajemen laba terjadi disebabkan dengan adanya benturan kepentingan antara pihak investor (principal) dan pihak manajemen (agent) yang dimana pihak manajemen ingin memaksimumkan utilitasnya (Scott 2000).

Ketidakselarasan tujuan antara pihak pemegang saham dan pihak manajemen dijelaskan dalam teori agensi (Jensen and Meckling 1976). Hubungan ketidakselarasan ini dapat memicu terjadinya asimetri informasi sehingga menyebabkan agen melakukan manipulasi terhadap laporan keuangan. Salah satu tanda terjadinya asimetri informasi yaitu saat manajer menguasai atau mengetahui lebih banyak informasi tentang internal perusahaan dan prospek kedepannya dibandingkan informasi yang diketahui investor. Degan mengetahui informasi lebih banyak, manajemen dapat melakukan praktek akuntansi dgn orientasi pada peningkatan keuntungan agar peningkatan kinerja entitas tercapai.

Ukuran suatu entitas merupakan factor lain yang mempengaruhi manajemen laba. (Nasution and Setiawan 2007) mengungkapkan bahwa ukuran perusahaan 
memiliki fungsi penting dalam pelaksanaan praktik manajemen laba. Praktik manajemen laba diperkirakan lebih banyak dilakukan entitas dengan ukuran yang kecil lebih daripada entitas berukuran besar. Karena informasi yang dibutuhkan investor untuk memutuskan berinvestasi semakin besar sesuai dengan ukuran entitas. Sehingga entitas besar cenderung lebih akurat dalam pelaporan keuangan oleh karena entitas besar mendapatkan pengawasan lebih oleh publik sehingga mereka harus memberikan informasi yang sesungguhnya. Hal yang berbeda terjadi pada perusahaan berukuran kecil, dimana mereka yang lebih banyak melakukan praktek manajemen laba. Hal tersebut dikarenakan entitas dengan ukuran kecil cenderung ingin memperlihatkan kondisi kinerja entitas yang meningkat tiap periode waktu agar investor berkeinginan/berniat berinvestasi pada entitas tertentu.

Praktik manajemen laba juga dipengaruhi oleh kepemilikan saham oleh karyawan. The National Center for Employe Ownership (2005) dalam BAPEPAM (2002) menyatakan bahwa Employee Stock Ownership (ESO) memberikan kesempatan bagi employee dalam membeli sejumlah saham tertentu suatu entitas. ESOP merupakan program benefit karyawan yang mirip dengan pembagian laba.

"Salah satu tujuan penerapan ESOP (Employee Stock Ownership Program) menciptakan keselarasan kepentingan serta misi dari pegawai dan pejabat eksekutif dengan kepentingan dan misi pemegang saham, sehingga tidak ada benturan kepentingan antara pemegang saham dan pihak-pihak yang menjalankan kegiatan usaha perusahaan (BEPEPAM, 2002).” 
Anak Agung Istri Sarasmitha Dewi dan I Gusti Ayu Nyoman Budiasih. Pengaruh ...

Sesuai pemaparan diatas, diambil kesimpulan bahwa ESOP merupakan metode terbaik untuk membuat manajer mengambil keputusan yang dapat meningkatkan nilai perusahaan. ESOP membuat employee dan manager sebuah entitas berperan sebagai pemilik sekaligus pengelola. Karena employee dan manager juga berperan sebagai pemilik, maka mereka akan melakukan kegiatan operasionalnya dengan efisien dan efektif. Hal tersebut akan meminimalisir pekerja dan pejabat eksekutif untuk menerapkan manajemen laba. Hal tersebut disebabkan karena pegawai dan eksekutif akan memperoleh baik dan buruk hasil dari keputusan yang dibuat, sehingga praktik ESOP berpengaruh negatif pada manajemen laba.

Asimetri informasi adalah keadaan saat manajemen perusahaan memiliki lebih banyak informasi kondisi internal perusahaan dibandingkan dengan pemilik saham. Teori keagenan menjelaskan tentang perusahaan titik temu hubungan keagenan antara pemilik perusahaan (principal) dan manajemen perusahaan (agent). Usaha memaksimalisasi keuntungan ini mendorong terjadinya konflik kepentingan antara principal dan agent karena setiap pihak berusaha memaksimalkan keuntungannya.

Banyak penelitian yang berkaitan dengan asimetri informasi. Salah satu diantaranya merupakan penelitian yang dilakukan oleh (Firdaus 2013) yang menemukan hasil bahwa asimetri informasi tidak berpengaruh terhadap manajeme laba. Kekeliruan perihal pelaporan keuangan pada masa sebelumnya menjadi salah satu kemungkinannya (Sulistyanto 2008). Namun, penelitian yang dilakukan oleh (Tarigan 2011) dan (Muliati 2011) menemukan bahwa asimetri informasi 
berpengaruh terhadap manajemen laba. Adanya asimetri informasi ini, manajemen perusahaan cenderung untuk menyajikan informasi yang tidak sebanarnya.

Asimetri informasi dianggap sebagai menjadi penyebab terjadinya manajemen laba. Ketika asimetri informasi tinggi, perusahaan dapat dengan mudah untuk memanipulasi laba sebelum laporan keuangan diaudit tanpa terdeteksi. Oleh karena itu, dengan tingginya informasi asimetri, maka kecenderungan bahwa perusahaan tidak akan dimonitor secara efektif semakin besar. Dengan besarnya resiko dan prospek pertumbuhan investasi perusahaan maka semakin kecil tingkat manajemen laba. Ini disebabkan karena asimetri informasi akan terjadi pada perusahaan dengan tingkat pertumbuhan investasi yang tinggi pula. Sedangkan semakin besar perusahaan, semakin besar pula tingkat manajemen labanya. Berdasarkan penjelasan di atas, hipotesis yang dapat dirumuskan dalam penelitian ini adalah:

$\mathrm{H}_{1}$ : Asimetri informasi berpengaruh positif pada praktik manajemen laba.

Teori yang mendasari pegaruh antara ukuran perusahaan dengan manajemen laba adalah signaling theory. Teori sinyal dengan asimetri informasi dapat terjadi bila antara salah satu pihak mempunyai informasi yang lebih lengkap daripada pihak lainnya (Rahmawati 2010). Didalam penilaian aktiva perusahaan, ukuran perusahaanlah yang sering digunakan. Nilai aktiva digunakan sebagai ukuran perusahaan karena sampai dengan saat ini masih terdapat compounding effect yang timbul karena perusahaan yang besar selalu diidentikkan dengan nilai aktiva yang besar pula. Keadaan ini menjadi motivasi bagi pihak manajemen untuk melalukan manajemen laba karena mereka percaya bahwa para pemakai laporan 
Anak Agung Istri Sarasmitha Dewi dan I Gusti Ayu Nyoman Budiasih. Pengaruh ...

keuangan mendasarkan penilaiannya mengenai perusahaan pada angka nilai aktiva.

(Nariastiti and Dwi Ratnadi 2014) menemukan bahwa ukuran perushaan berpengaruh negatif terhadap manajemen laba. Perusahaan besar dinilai kurang memiliki motivasi didalam melakukan praktik manajemen laba. Hal ini disebabkan karena pemegang saham dan para pemilik kepentingan di perusahaan tersebut dianggap lebih kritis dibandingkan dengan perusahaan kecil. Pada perusahaan besar investor memiliki basis yang lebih besar, sehingga perusahaan tersebut mendapat tekanan yang lebih kuat untuk dapat menampilkan laporan keuangan yang dapat dipercaya (Nasution and Setiawan 2007).

Ukuran perusahaan mempengaruhi manajemen laba karena pihak manajemen tidak menyampaikan semua informasi. Banyak anggapan yang terjadi bahwa selama ini para manajer dianggap masih percaya bahwa para pemakai laporan keuangan telah mendasarkan penilaiannya mengenai perusahaan pada nilai total aktiva. Motivasi baru akan muncul dan para manajer akan termotivasi untuk melakukan tindakan tersebut dan menimbulakan kesan yang lebih baik mengenai perusahaannya kepada pihak pemakai laporan keuangan. Berdasarkan penjelasan di atas, hipotesis yang dapat dirumuskan dalam penelitian ini adalah:

$\mathrm{H}_{2}$ : Ukuran perusahaan berpengaruh negatif pada praktik manajemen laba

Employee Stock Ownership Program (ESOP) adalah pemberian hak opsi kepada karyawan untuk membeli sebagian saham perusahaan dalam suatu periode tertentu pada tingkat harga yang sudah ditentukan ketika opsi diberikan (Telaumbuana 2000). Konsep opsi saham karyawan sebagai hak yang dihadiahkan 
perusahaan kepada karyawannya untuk membeli sejumlah saham perusahaan pada harga yang telah ditentukan selama periode tertentu juga didefinisikan oleh (Little 2001).

ESOP memiliki tujuan untuk menciptakan hubungan keselarasan dan kepentingan dari pegawai dan pejabat dengan kepentingan pemegang saham, sehingga benturan kepentingan antara pemegang saham dengan pihak-pihak yang menjalankan kegiatan perusahaan dapat diminimalisir. Pernyataan ini menyimpulkan bahwa penerapan dari ESOP dapat menjadikan pegawai dan pejabat eksekutif perusahaan sebagai pemilik dan pengelola perusahaan akan termotivasi untuk meningkatakan kinerjanya dengan melakukan kegiatan operasional yang efektif dan efisien. Efek yang ditimbulkan yaitu dapat meminimalisir adanya praktik manajemen laba karena kinerja perushaan yang baik. Hal ini teah dibuktikan dengan penelitian yang dilakukan oleh (Maiyusti 2014) yang menunjukkan bahwa penerapan ESOP berpengaruh negatif pada manajeen laba.

Employee stock ownership program merupakan kebijakan jangka panjang perusahaan yang dapat mengatasi sikap manajer yang oportunistik. Tindakan manajemen pada program ini dapat memotivasi manajer untuk lebih meningkatkan kompetensinya dan juga diharapkan dapat mengurangi konflik kepentingan antara manajemen dan pemilik saham. Berdasarkan penjelasan di atas, hipotesis yang dapat dirumuskan dalam penelitian ini adalah:

$\mathrm{H}_{3}$ : Employee stock ownership program berpengaruh negatif pada praktik manajemen laba 
Anak Agung Istri Sarasmitha Dewi dan I Gusti Ayu Nyoman Budiasih. Pengaruh ...

\section{METODE PENELITIAN}

Penelitian ini berdasarkan pendekatan kuantitatif berbentuk asosiatif. Penelitian tentang pendekatan yang berbentuk asosiatif juga dikemukakan oleh (Sugiyono 2016) yang menyatakan bahwa peneltian asosiatif merupakan jenis penelitian yang menjelaskan pengaruh dari variabel bebas dengan variabel terikat. Populasi pada penelitian ini yaitu seluruh entitas yang listing di BEI pada periode 20142016 diperoleh dengan cara mengakses hhtp://www.idx.co.id. Sampel ini berdasarkan pendekatan non-probability dengan menggunakan teknik purposive sampling dengan jumlah sampel sebanyak 14 perusahaan. Objek dari penelitian ini adalah seluruh perusahaan yang terdaftar di BEI periode tahun 2014-2016. Objek didalam penelitian ini ialah manajemen laba yang dipengaruhi oleh asimetri informasi, ukuran perusahaan, dan employee stock ownership program.

Penelitian ini mengidentifikasikan adanya dua jenis variabel, yaitu variabel terikat ialah variabel yang menjadi akibat dari adanya variabel bebas. Variabel terikat didalam penelitian ini ialah earnings management/manajemen laba. Sedangkan, variabel bebas adalah merupakan variabel yang memengaruhi atau yang menjadi sebab perubahannya atau timbulnya variabel dependen (terikat). Variabel ini juga sering disebut sebagai variabel stimulus, predictor, antecendent. Variabel independen/bebas dalam penelitian ini adalah asimetri Informasi $\left(\mathrm{X}_{1}\right)$, ukuran perusahaan $\left(\mathrm{X}_{2}\right)$, dan employee stock ownership program $\left(\mathrm{X}_{3}\right)$.

Variabel dependen pada penelitian manajemen laba ini ditunjukkan dengn nilai discretiannary acrualls. Discretionary accruals dihitung menggunakan model Modified Jones Model (Dechow, Sloan, and Sweeney 1995). Asimetri 
informasi, ukuran perusahan, dan ESOP menjadi variabel independen dari penelitian ini. Data-data mengenai variabel independen ini diperoleh dari laporan keuangan perusahaan.

Definisi dari operasional variabel ini merupakan suatu pengertian yang dinyatakan dalam bentuk istilah yang diuji secara spesifik atau dengan pengukuran kriteria. Definisi operasional masing-masing variabel dalam penelitian ini adalah sebagai berikut.

Pada penelitian ini manajemen laba digunakan sebagai variabel terikat dengan proksi discretionary accrual (DA) model (Jones 1991). (Asyik 2006), (F and Trisnawati 2008), dan (Astika 2008) didalam penelitiannya juga telah menggunakan model ini untuk mengukur manajemen laba.

Tait $=($ Laba bersih - Arus kas dari operasi $) /$ Ait -1

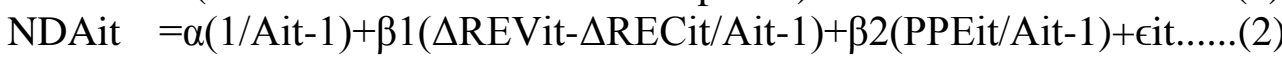

DAit $=$ TAit - NDAit.

TAit merupakan total akrual perusahaan i pada periode t, Ait-1 merupakan total aset peusahaan i pada periode $\mathrm{t}-1, \Delta \mathrm{REVit}$ merupakan perubahan pendapatan perusahaan i pada periode $\mathrm{t}, \triangle \mathrm{RECit}$ merupakan perubahan piutang perusahaan $\mathrm{i}$ pada periode $t$, PPEit merupakan property, plant and equipment perusahaan i periode t, DAit merupakan discretionary accrual perusahaan i pada periode $t$, dan NDAit merupakan non-discretionary accrual perusahaan i pada periode t.

Hasil dari discretionary accrual (DA) ini dikalikan dengan -1 yangbdimana akan memperoleh hasil beta positif dikarenakan earning management menurun menjadi beta negatif, sehingga konsep dan hasil akan terjadi keselarasan. Hal ini dilakukan oleh penelitian (Riahi and Belkaoui 2012) dan (Astika 2008). 
Anak Agung Istri Sarasmitha Dewi dan I Gusti Ayu Nyoman Budiasih. Pengaruh ...

Ketika para manajer lebih mengetahui informasi-informasi internal dan prospek perusahaan di masa mendatang dibandingkan dengan stakeholder dan pemegang saham lainnya asimetri informasi akan muncul. Penelitian ini mengukur asimetri informasi dengan menggunakan relative bid-ask spread (Rahmawati 2007) yang dioperasikan sebagai berikut:

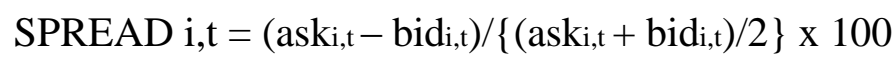

Keterangan:

Aski, $\mathrm{t}=$ Harga ask tertinggi saham perusahaan i yang terjadi pada hari $\mathrm{t}$ Bidi, $\mathrm{t}=$ Harga bid terendah saham perusahaan i yang terjadi pada hari $\mathrm{t}$

Bid-ask spread sebagai proksi dari asimetri informasi dihitung sebagai ratarata selama 12 bulan (Januari-Desember) dari perhitungan di atas untuk tiap tahun periode penelitian.

Ukuran perusahaan menunjukkan besar kecilnya suatu perusahaan. (Asnawi and Wijaya 2005) menentukan ukuran perusahaan dengan menggunakan logaritma natural (Ln) dari total asset. Secara matematis ukuran perusahaan dapat dirumuskan sebagai berikut:

$$
\text { Ukuran Perusahaan }=\text { Ln of Total Asset } \text {. }
$$

Variabel independen adalah proporsi opsi saham yang diproksi dengan proporsi opsi saham karyawan (PESOP). Proksi ini telah digunakan oleh (Asyik 2006) dan (Astika 2008) untuk mengukur ESOP dengan formula sebagai berikut.

$$
\mathrm{PESOP}=\frac{\mathrm{JOS}}{\mathrm{JSB}}
$$

ESOP merupakan proporsi opsi saham karyawan, JOS merupakan jumlah opsi saham yang dihibahkan, dan JSB merupakan jumlah saham yang beredar awal atau akhir tahun sebelumnya (t-1). 
Pada penelitian ini purposive sampling merupakan teknik sampel yang digunakan. Menurut (Sugiyono 2016) purposive sampling adalah teknik untuk menentukan sampel penelitian dengan beberapa pertimbangan tertentu yang bertujuan agar data yang diperoleh nantinya bisa lebih representatif. Pertimbangan-pertimbangan atau kriteria penentuan sampel dalam penelitian ini adalah sebagai berikut.

Perusahaan yang memiliki data mengenai kepemilikan saham oleh manjemen (kepemilikan manjerial) secara berturut-turut dari tahun 2014-2016. Perusahaan yang sahamnya masih aktif diperdagangkan di Bursa Efek Indonesia. Menurut Surat Edaran Bursa Efek Jakarta No. SE-03/BEJ/II-1/1994, kriteria saham aktif yang diperdagangkan adalah saham yang memiliki frekuensi perdagangan minimal 300 kali atau lebih setiap tahunnya. Jika suatu saham memiliki frekuensi perdagangan dibawah standar tersebut, maka saham tersebut dikategorikan sebagai saham tidak aktif atau saham tidur. Saham tidur cenderung berkinerja buruk yaitu tidak mengalami pertumbuhan kinerja. Para investor akan menghindari berinvestasi pada saham tidur ini sebab berinvestasi pada perusahaan yang yang sahamnya tidak aktif tidak menjanjikan return yang tinggi. Perusahaan yang tidak pernah mengalami delisting. Sesuai dengan peraturan pencatatan saham di Bursa Efek Indonesia, jika suatu perusahaan bangkrut atau dilikuidasi maka secara otomatis perusahaan tersebut akan dikeluarkan dari bursa. Fenomena delisting akan membuat kepercayaan pasar terhadap perusahaan yang terdaftar di bursa akan merosot. Kondisi ini bukan saja berdampak pada lemahnya keinginan 
masyarakat berinvestasi melalui pasar modal, tetapi juga mengurangi tingkat kepercayaan kepada pasar modal.

Metode yang digunakan adalan metode observasi non partisipan dimana peneliti tidak terlibat secara langsung dalam proses observasi tapi hanya sebagai pengamat independen. Penelitian ini dilakukan bersumber dari website Bursa Efek Indonesia yaituww.idx.co.id, buku-buku, skripsi-skripsi dan jurnal-jurnal yang terkait.

Jenis data didalam penelitian ini ialah data kuantitatif. Menurut (Sugiyono 2016) metode penelitian kuantitatif diartikan sebagai metode penelitian yang berlandaskan pada filsafat positivisme dan digunakan untuk meneliti pada populasi atau sampel tertentu. Sumber data yang digunakan dalam penelitian ini adalah data sekunder. Menurut (Sugiyono 2016) data sekunder adalah data yang diperoleh dari catatan-catatan yang ada pada perusahaan dan dari sumber lainnya yaitu dengan studi kepustakaan. Sumber data pada peneitian ini yaitu data yang diperoleh langsung dari Bursa Efek Indonesia berupa 23 perusahaan yang go public di Bursa Efek Indonesia untuk periode tahun 2014-2016. Sumber data dalam penelitian ini merupakan data sekunder yang berasal dari Bursa Efek Indonesia (BEI) dan download di situs www.idx.co.id.

Uji asumsi klasik dilakukan sebelum menguji dan menganalisis data dengan bantuan program SPSS. Pengujian asumsi klasik bertujuan untuk lebih meyakinkan atas kelayakan model yang dibuat, terutama untuk tujuan memprediksi (Suyana Utama 2014). 
Uji normalitas adalah pengujian yang dilakukan guna mengetahui apakah dalam model regresi variabel terikat dengan variabel bebas mempunyai distribusi normal atau tidak normal. Model regresi yang baik adalah memiliki distribusi residual yang normal atau mendekati normal (Suyana Utama 2014). Metode yang digunakan adalah dengan uji Kolmogoro-Smirnov (K-S). Data populasi dikatakan berdistribusi normal jika nilai signifikansi (2-tailed) K-S lebih besar dari tingkat alpha, $\alpha=0,05$.

Uji multikoliniearitas dilakukan untuk menguji apakah model regresi ditemukan adanya korelasi antar variabel bebas (independen). Model regresi yang baik seharusnya tidak mengandung korelasi di antara variabel independen (Ghozali 2013). Multikolinearitas dapat dilihat dari nilai tolerance VIF (Variance Inflating Factor). Jika nilai tolerance lebih dari 10 persen atau VIF kurang dari 10, maka dikatakan tidak ada multikolinearitas (Suyana Utama 2014).

Uji heteroskedastisitas dilakukan untuk menguji apakah dalam sebuah model regresi terjadi ketidaksamaan varians dari residual atas suatu pengamatan ke pengamatan lain. Jika varians dari residual suatu pengamatan ke pengamatan lain tetap, maka disebut homokedastisitas dan jika berbeda disebut heterokedastisitas. Model regresi yang baik adalah model yang tidak mengandung gejala heteroskedastisitas atau mempunyai varian yang homogen. Pengujian ini dilakukan dengan uji Glejser yaitu dengan cara mengregresi nilai absolute residual dari model yang diestimasi terhadap variable independen. Jika nilai signifikansinya lebih besar dari $0,05($ sig $\geq 0,05)$ maka dikatakan model regresi bebas dari heteroskedastisitas (Ghozali 2013). 
Anak Agung Istri Sarasmitha Dewi dan I Gusti Ayu Nyoman Budiasih. Pengaruh ...

Autokorelasi berarti terdapatnya korelasi antara anggota sampel atau data. Uji autokorelasi bertujuan untuk menguji apakah dalam model regresi linear terdapat korelasi antara kesalahan pengganggu pada periode t dengan kesalahan pengganggu periode t-1 (sebelumnya) (Ghozali 2013). Pengujian autokorelasi yang banyak digunakan adalah model Durbin-Watson (DW-test). Jika sudah terdapat nilai $D W$-test, maka nilai tersebut kemudian dibandingkan dengan nilai tabel menggunakan tingkat keyakinan 95\% (Suyana Utama 2014). Kriteria pengujian Durbin-Watson adalah sebagai berikut: Bila du $<$ dw (4-du), maka tidak terjadi autokorelasi, Bila $\mathrm{dw}<\mathrm{dl}$, maka terjadi autokorelasi, Bila $\mathrm{dw}>(4-\mathrm{dl})$, maka terjadi autokorelasi, Bila $\mathrm{dl}<\mathrm{dw}<\mathrm{du}$ atau $(4-\mathrm{du})<\mathrm{dw}<(4-\mathrm{dl})$, maka tidak dapat ditarik kesimpulan mengenai ada tidaknya autokorelasi.

Analisis regresi linear berganda digunakan untuk mengetahui atau memperoleh gambaran mengenai pengaruh variabel bebas $\left(X_{1}, X_{2}, X_{3}\right.$ dan $\left.X_{4}\right)$ terhadap variabel terikat (Y). Analisis ini dillakukan dengan menggunakan bantuan program komputer Statistical Package for Sosial Science (SPSS). Model regresi linear berganda ditunjukkan dengan persamaan sebagai berikut.

$Y=\alpha+\beta_{1} X_{1}+\beta_{2} X_{2}+\varepsilon+\beta_{3} X_{3}+\beta_{4} X_{4}$

Keterangan:

$\mathrm{Y}=$ Manajemen laba

$\alpha \quad=$ Konstanta

$\beta_{1,2,3,4}=$ Koefisien regresi dari setiap variabel independen

$\varepsilon=$ error

$\mathrm{X}_{1} \quad=$ Asimetri Informasi

$\mathrm{X}_{2} \quad=$ Ukuran perusahaan

$\mathrm{X}_{3} \quad=$ Konservatisme akutansi

$\mathrm{X}_{4} \quad=$ Employee stock ownership program 
Keofisien determinasi ( $\left.\mathrm{R}_{2}\right)$ menunjukkan proporsi yang diterangkanoleh variabel bebas dalam model terhadap variabel terikatnya. Koefisien determinasi menunjukkan besarnya persentase sumbangan $\mathrm{X}_{1}, \mathrm{X}_{2}$, dan $\mathrm{X}_{3}$ terhadap $\mathrm{Y}$, dimana $0<\mathrm{R}_{2}<1$. Hal ini berarti nilai $\mathrm{R}_{2}$ yang sudah mendekati 1 merupakan indikator yang menunjukkan semakin kuatnya pengaruh variabel independen terhadap variabel dependen.

Uji F statistik menunjukkan apakah semua variabel bebas didalam suatu penelitian yang dimasukkan dalam model regresi mempunyai pengaruh secara bersama-sama terhadap variabel terikat (Ghozali 2013). Setelah F garis regresi ditentukan hasilnya lalu $\mathrm{F}$ garis regresi tersebut kemudian dibandingkan dengan $\mathrm{F}$ tabel.

Untuk menentukan nilai $\mathrm{F}$ tabel, tingkat signifikansi yang digunakan adalah sebesar $\alpha=5 \%$ dengan tingkat kebebasan (degree of freedom) df $=(n-k)$ dimana $n$ adalah jumlah observasi dan $\mathrm{k}$ adalah jumlah variabel. Jika $\mathrm{F}$ hitung $>\mathrm{F}$ tabel maka hal ini berarti variabel bebas mampu menjelaskan variabel terikat secara bersama-sama. Sebaliknya jika $\mathrm{F}$ hitung $<\mathrm{F}$ tabel maka hal ini berarti variabel bebas secara bersama-sama tidak mampu menjelaskan variabel terikatnya.

Uji statistik t digunakan untuk menguji seberapa jauh pengaruh variabel independen yang digunakan dalam penelitian ini secara individual dalam menerangkan variabel dependen (Ghozali 2013). Uji statistik t diketahui melalui hasil regresi yang dilakukan menggunakan program SPSS, yaitu dengan membandingkan tingkat signifikansi masing-masing variabel bebas dengan $\alpha=$ 
Anak Agung Istri Sarasmitha Dewi dan I Gusti Ayu Nyoman Budiasih. Pengaruh ...

0,05. Apabila tingkat signifikansi $\mathrm{t}<\alpha=0,05$ maka $\mathrm{H}_{0}$ ditolak, dan sebaliknya jika tingkat signifikansi $\mathrm{t} \geq \alpha=0,05$ maka $\mathrm{H}_{0}$ diterima.

\section{HASIL DAN PEMBAHASAN}

Berdasarkan proses seleksi sampel penelitian, perusahaan-perusahaan yang terdaftar di BEI dan yang mengadopsi Employee Stock Option Program (ESOP) dari periode 1 Januari 2014 sampai dengan 31 Desember 2016 adalah sebanyak 14 perusahaan. Sampel dari penelitian ini diperoleh dari laporan keuangan per tahun dengan rupiah sebagai mata uang pelaporan.

Adapun pengujian yang digunakan didalam penelitian ini yaitu uji asumsi klasik yang terdiri dari uji multikolinearitas, heteroskedastisitas, dan normalitas. Hasil uji normalitas yang diuji dengan menggunakan Kolmogorov-Smirnov test menunjukan nilai Asimp. Sig. (2-tailed) sebesar 0,92 lebih besar dari nilai $\alpha$ $(0,05)$. Hal tersebut menandakan bahwa data terdistribusi normal. Hasil dari uji multikolinearitas ini menunjukan bahwa hasil nilai VIF dari masing-masing variabel independen lebih kecil dari 10, maka dari itu dapat disimpulkan bahwa dalam model ini tidak terjadi gejala multikolinearitas antar variabel independen. Hasil uji heteroskedastisitas dgn menggunakan metode Gleyser menunjukan nilai signifikansi masing-masing variabel sebesar 1,000 dan lebih besar dari $\alpha$. Hal tersebut menandakan bahwa gejala heteroskedastisitas pada model tidak ditemui.

Setelah dilaksanakan uji asumsi klasik, hasil menunjukan data terdistribusi normal. Dari hasil pengujian, diperoleh hasil bahwa tidak terdapat gejala multikolinearitas antar variabel independen dan gejala heteroskedastisitas tidak 
ditemukan. Sehingga data yang tersedia telah memenuhi syarat serta selanjutnya dapat diuji menggunakan model regresi linear berganda.

Setelah melewati uji asumsi klasik, uji t dilaksanakan untuk menguji hipotesis penelitian. Hasil analisis uji t dipaparkan pada Tabel 1.

Tabel 1.

Hasil Analisis Ujia t

\begin{tabular}{llll}
\cline { 2 - 4 } 1 & (Constant) &, 673 &, 505 \\
& Asimetri Informasi & 1,617 &, 114 \\
& Ukuran Perusahaan &,- 614 &, 543 \\
& $\begin{array}{l}\text { Employee Stock } \\
\text { Ownership Program }\end{array}$ & $-3,218$ &, 003 \\
\hline
\end{tabular}

Berdasarkan hasil pengujian hipotesis, variabel asimetri informasi menunjukan koefisien senilai 1,617. Koefisien regresi menunjukan nilai positif dengan tingkat signifikan lebih besar dari $\alpha(\alpha=0,005)$. Hal tersebut menunjukan bahwa asimetri informasi tidak mempengaruhi manajemen laba, sehingga hipotesis pertama $\left(\mathrm{H}_{1}\right)$ ditolak. Dapat disimpulkan bahwa asimetri informasi bukan salah satu faktor yang sangat diperhitungkan dalam manajemen laba. (Jensen and Meckling 1976) menyatakan agent \& principal berupaya memaksimalkan keuntungan merekasendiri serta memiliki motivasi \& kepentingan yang tidak sama, sehingga menimbulkan argument yang mendukung bahwa tidak selamanya agent akan mengikuti keinginan principal.

Variabel ukuran perusahaan memiliki nilai koefisien -,614 dengan tingkat signifikan 0,543. Koefisien regresi menunjukan nilai negatif dengan tingkat signifikansi lebih besar dari nilai $\alpha$. Hal tersebut berarti bahwa ukuran perusahaan tidak mempengaruhi pada praktik manajemen laba, sehingga hipotesis kedua $\left(\mathrm{H}_{2}\right)$ ditolak. (Jensen and Meckling 1976) menyatakan bahwa banyaknya 
Anak Agung Istri Sarasmitha Dewi dan I Gusti Ayu Nyoman Budiasih. Pengaruh ...

pengungkapan yang perlu diungkapkan oleh suatu entitas tergantung dari seberapa besar ukuran entitas tersebut. Pernyataan ini mendasari teori agensi yang memaparkan bahwa pengungkapan lebih banyak dilakukan oleh perusahaan yang lebih besar \& hal tersebut meningkatkan biaya keagenan. Pengungkapan yang lebih banyak biasanya diungkapkan oleh entitas guna mengurangi biaya keagenan tersebut. Entitas yang berukuran besar biasanya memiliki permintaan publik akan informasi lebih tinggi dibandingkan dengan entitas yang kecil. Maka, ada alasan untuk percaya bahwa dalam menentukan adanya praktek manajemen laba, entitas tidak dapat dijadikan tolak ukur.

Variabel employee stock owership program setelah dilakukan uji menunjukan nilai koefisien sebesar -3,218 dengan tingkat signifikansi sebesar 0,003. Koefisien regresi menunjukan nilai negatif dengan tingkat signifikansi lebih kecil dari $\alpha(\alpha=0,005)$. Hal tersebut berarti bahwa ukuran perusahaan berpengaruh pada praktik manajemen laba. Dapat disimpulkan hipotesis kedua $\left(\mathrm{H}_{2}\right)$ diterima. Kepemilikan saham oleh karyawan akan menyejajarkan kepentingan karyawan dengan kepentingan pemegang saham. ESOP yang diterapkan pada perusahaan diharapkan dapat mengurangi masalah terkait keagenan \& menurunkan biaya keagenan melalui penyelarasan kepentingan para manajemen dengan para investor, sehingga para manajemen merasa bahwa diri mereka lebih dari sekedar karyawan dalam sebuah perusahaan tetapi dia memiliki sense of belonging yang berakibat karyawan semakin termotivasi untuk meningkatkan kinerja perusahaan. Untuk menyejajarkan kepentingan manajemen 
dengan kepentingan investor, manajemen harus memiliki kepemilikan saham (Jensen and Meckling 1976).

Berdasarkan hasil penelitian dan pembahasan yang telah dijelaskan, maka penelitian ini mempunyai beberapa implikasi sebagai berikut:

Penelitian ini dapat mendukung teori keagenan terkait dengan Asimetri Informasi, Ukuran Perusahaan, dan Employee Stock Ownership Program (ESOP). Adanya pelaksanaan ESOP di suatu perusahaan, diharapkan dapat mengurangi konflik keagenan yang terjadi antara pemilik dan karyawan. Pemberian opsi saham pada karyawan dapat memotivasi kinerja para karyawan untuk bekerja semaksimal mungkin. Selain mempertimbangkan konflik internal yang terjadi antara pemilik dan karyawan, perusahaan juga memperhatikan konflik yang mungkin terjadi dengan kreditor.

Bagi peneliti berikutnya, penelitian ini dapat dijadikan sebagai referensi dalam penelitian berikutnya mengenai ESOP. Dengan menambahkan variabelvariabel lain yang dapat mempengaruhi pelaksanaan ESOP, sehingga dapat menambah kajian mengenai penelitian ESOP.

Bagi perusahaan, penelitian ini dapat memberikan informasi mengenai dampak dari kinerja perusahaan dengan adanya pelaksanaan ESOP.

Bagi investor, penelitian dapat dijadikan sebagai pertimbangan bagi investor dalam mengambil keputusan terkait dengan investasi pada perusahaan-perusahaan yang menyelenggarakan ESOP. 


\section{SIMPULAN}

Berdasarkan hasil uji dan pemaparan sebelumnya, disimpulkan bahwa asimetri informasi dan ukuran perusahaan tidak mempengaruhi praktek manajemen laba, sedangkan ESOP berpengaruh pada praktik manajemen laba. Manajemen laba yang dilakukan perusahaan merupakan dampak dari semakin banyaknya jumlah opsi saham yang dihibahkan oleh perusahaan. Pelaksanaan ESOP yang mampu meningkatkan keuntungan karyaan, membuat karyawan termotivasi untuk mencapai target yang diberikan pemilik. Pelaksanaan ESOP membantu dalam penyelarasan kepentingan para karyawan dan pejabat eksekutif sehingga tidak terjadi ketidakselarasan kepentingan antara pemegang saham dan manajemen entitas untuk menerapkan manajemen laba.

Pemegang saham diharapkan dapat menggunakan informasi tentang ESOP sebagai acuan dalam memutuskan untuk berinvestasi atau tidak. Bagi entitas, diharapkan dapat melihat bahwa pemberian opsi saham bagi karyawan dapat meningkatkan motivasi karyawan sehingga kinerja perusahaan makin membaik. Untuk peneliti berikutnya, diharapkan dapat menggunakan variable yang berbeda yang diduga dapat mempengaruhi manajemen laba, seperti: leverage, kualitas audit, kinerja masa depan, dan kinerja masa kini.

\section{REFRENSI}

Asnawi, S.K., and C. Wijaya. 2005. Riset Keuangan: Pengujian-Pengujian Empiris. Jakarta: PT Gramedia Pustaka Utama.

Astika, I.B.P. 2008. "Pembentukan Return Saham Ekspektasian Melalui Manajemen Laba Di Sekitar Peristiwa Pengumuman Program Opsi Saham Karyawan.” Jurnal Aplikasi Manajemen Vol. 8, No. 
Asyik, N.F. 2006. "Dampak Penyataan Dan Nilai Wajar Opsi Saham Pada Pengaruh Magnituda Kompensasi Program Opsi Saham Karyawan Terhadap Pengelolaan Laba.” Simposium Nasional Akuntansi 9, Padang.

Dechow, P.M., R.G. Sloan, and A.P. Sweeney. 1995. "Detecting Earning Management." The Accounting Review Vol. 70, N: 192-225.

F, Anggraini, and I Trisnawati. 2008. "Pengaruh Earning Management Terhadap Konservatisme Akuntansi." Jurnal Bisnis dan Akuntansi 10 (1): 23-36.

Fahmi, Irham. 2015. Pengantar Teori Portofolio Dan Analisis Investasi. Bandung: Alfabeta.

Firdaus, Ilham. 2013. "Pengaruh Asimetri Informasi Dan Capital Adequacy Ratio Terhadap Manajemen Laba Pada Perusahaan Perbankan Yang Listing Di Bursa Efek Indonesia.” Negeri Padang.

Ghozali, Imam. 2013. Aplikasi Analisis Multivariate Dengan Program IBM SPSS 21 Update PLS Regresi. Semarang: Badan Penerbit Universitas Diponegoro.

Jensen, M.C., and W.H Meckling. 1976. "Theory of The Firm: Managerial Behavior, Agency Cost and Ownership Structure." Journal of Financial Economics3: hal. 305-360.

Jones, J.J. 1991. "Earnings Management During Import Relief Investigations." Journal of Accounting Researh Vol. 29, N: 193-228.

Little, K. 2001. Ten Minute Guide to Employee Stock Option Purchase Plans. PT Andi Corptight.

Maiyusti, Anisa. 2014. "Pengaruh Asimetri Informasi, Kepemilikan Manajerial Dan Employee Stock Ownership Program Terhadap Praktik Manajemen Laba (Perusahaan Manufaktur Yang Terdaftar Di Bursa Efek Indonesia Tahun 2007-2012)." Jurnal Akuntansi Fakultas Ekonomi Universitas Negeri Padang.

Muliati. 2011. "Pengaruh Asimetri Informasi Dan Ukuran Perusahaan Pada Praktik Manajemen Laba Di Perusahaan Perbankan Yang Terdaftar Di BEI.” Universitas Udayana, Denpasar.

Nariastiti, Ni Wayan, and Made Dwi Ratnadi. 2014. "Pengaruh Asimetri Informasi, Corporate Governance Dan Ukuran Perusahaan Pada Manajemen Laba.” E-Jurnal Akuntansi Universitas Udayana 9.3 : 717-727. ISSN : 2302 -8556 . 
Nasution, M., and D. Setiawan. 2007. "Pengaruh Corporate Governance Terhadap Manajemen Laba Di Industri Perbankan Indonesia." Simposium Nasional Akuntansi X.

Rahmawati. 2007. "Pengauh Asimetri Informasi Terhadap Praktik Manajemen Laba Pada Perusahaan Perbankan Publik Yang Terdaftar Di Bursa Efek Jakarta." The Indonesian Journal of Accounting Research 10(1).

Rahmawati, Fitri. 2010. "Model Pendeteksian Manajemen Laba Pada Industri Perbankan Publik Di Indonesia Dan Pengaruhnya Terhadap Kinerja Perbankan." AKuntansi dan Manajemen 18(1): 23-24.

Riahi, Ahmed, and Belkaoui. 2012. Teori Akuntansi. Edisi Ke 5, Buku 2. Jakarta: Salemba Empat.

Scott, R.W. 2000. "Financial Accounting Theory" 2nd Edition. Prentice Hall International Inc. New Jersey.

Sugiyono. 2016. Metodologi Penelitian: Kuantitatif, Kualitatif, Dan R\&D. Bandung: Alfabeta Bandung.

Sulistyanto, Sri. 2008. Manajemen Laba Teori Dan Model Empris. Jakarta: Grasindo.

Suyana Utama, Made. 2014. Aplikasi Analisis Kuantitatif. Edisi Ke-8. Buku Ajar Kuliah pada Fakultas Ekonomi dan Bisnis Universitas Udayana.

Tarigan, T.C. 2011. "Pengaruh Asimetri Informasi, Corporate Governance, Dan Ukuran Perusahaan Terhadap Praktik Manajemen Laba." Universitas Pembangunan Nasional "Veteran" Yogyakarta.

Telaumbuana, F.F. 2000. “Opsi Saham Karyawan.” Bisnis Indonesia. 